\title{
Spatial differences in investment outlays of micro and small enterprises in Poland
}

\author{
Katarzyna Ziętek-Kwaśniewska*
}

\begin{abstract}
Purpose - The aim of this paper is to analyse the spatial differences in the investment outlays of micro and small enterprises in Poland at the level of voivodeships in 2009-2015.

Design/methodology/approach - The research was conducted on the basis of CSO data for the years 20092015. The research methods used in the paper include an analysis of the structure and dynamics of the investment outlays of non-financial micro and small entities. With the aim to assess the investment activity of micro and small enterprises, investment outlays per entity, investment outlays per person employed, and the ratio of investment outlays to revenues were calculated.

Findings - Analysis of CSO data for the years 2009-2015 reveals differences between voivodeships in the investment activity of micro and small enterprises measured by investment outlays per entity, investment outlays per person employed, and the ratio of investment outlays to revenues.

Originality/value - Since a lot of research concerns small and medium-sized enterprises (SMEs) as a group, this article, which focuses on the investment activity of micro and small entities separately, makes a contribution to the literature on the functioning of micro and small enterprises in Poland.
\end{abstract}

Keywords: investment outlays, investment activity, micro and small enterprises

\section{Introduction}

Investments play a crucial role for every enterprise, regardless of its size. Their significance for the proper running of a business is beyond question. It has been stated that from an enterprise's perspective, investments are a necessary factor for modernization, development and growth of its competitive position in the market (Szafraniec-Siluta et al., 2012). Sooner or later, every enterprise is confronted with the need of investing and finding sources for financing its investment activity - otherwise, the one that does not invest inevitably decreases its chances for development and survival in the market. As Skowronek-Mielczarek (2013) notes, investments are the only way enabling expansion and continuous growth of the profitability and value of an enterprise.

The issue of the investment activity of businesses in Poland has been the subject of diverse studies. For example, Czerwonka and Jaworski analysed the sources of financing investments in fixed assets (2014a) and in intangible assets (2014b) made by economic entities employing more than 49 people in Poland in the years 2001-2010. Jaworek and Kuzel (2013)

\footnotetext{
* Katarzyna Ziętek-Kwaśniewska, PhD, Institute of Economics and Management, The John Paul II Catholic University of Lublin, Al. Racławickie 14, 20-950 Lublin, e-mail: kwasniewska@kul.lublin.pl.
} 
focused on the investment activity of the largest companies in Poland. Starzyńska (2016) assessed the investment activity of SMEs taking into account their ownership structure (companies with and without foreign capital) and size. Piwowarski (2014) studied the relation between the revenues and investments of SMEs in Poland. Jędrzejczak-Gas assessed the investment activity of small and medium-sized enterprises (SMEs) in the Lubuskie Voivodeship (2014) and in the Dolnośląskie Voivodeship (2016).

As the investment activity of enterprises is not homogeneous in character, the aim of this paper is to analyse the spatial differences in investment outlays of micro and small enterprises in Poland at the level of voivodeships in 2009-2015. In particular, while microenterprises are the dominant group of enterprises ${ }^{1}$, still there is a shortage of research on their functioning, decision making, and performance. Therefore, by empirically examining the investment activity of micro and small enterprises in Poland, this paper makes a contribution to the literature on the area mentioned above.

The remainder of this paper is organised as follows. Section 1 presents the research methods used in the analysis. Sections 2 and 3 discuss the results of an empirical study conducted on the basis of the Central Statistical Office of Poland (hereafter referred to as CSO) data for the years 2009-2015. While Section 2 provides information on the investment activity of micro and small enterprises in Poland in the period in question, Section 3 presents a more detailed analysis of the investment outlays of these entities at the level of voivodeships. The paper ends with concluding remarks.

\section{Data sources and research methods}

The research was conducted on the basis of CSO data for the years 2009-2015 presented in the publications Activity of non-financial enterprises ${ }^{2}$. An analysis was carried out for entities with less than ten persons employed (further on referred to as 'micro-enterprises') and entities with 10-49 persons employed (further on referred to as 'small enterprises'). According to the definition used by the CSO, by the term 'investment outlays', 'financial or tangible outlays, the purpose of which is the creation of new fixed assets or the improvement (rebuilding, enlargement, reconstruction or modernization) of existing capital asset items, as well as outlays on so-called initial investments' were meant (CSO, 2015, p. 21).

The research methods used in this paper include an analysis of the structure and dynamics of investment outlays of non-financial micro and small entities. With the aim to assess the investment activity of the enterprises in question, the following ratios were used:

\footnotetext{
${ }^{1}$ According to CSO data, in 2015, micro-enterprises constituted $96.0 \%$ of the total number of non-financial enterprises in Poland (Central Statistical Office, 2016).

${ }^{2}$ The data presented in the CSO's publications Activity of non-financial enterprises do not include entities classified according to the Polish Classification of Activities 2007 to section A (Agriculture, forestry and fisheries), $\mathrm{K}$ (Financial and insurance activities), and $\mathrm{O}$ (Public administration and defense; compulsory social security).
} 
investment outlays per entity, investment outlays per person employed, and investment outlays to revenues.

With regard to the analysis at the level of voivodeships, the data on investment outlays were presented according to the headquarters of the enterprise.

\section{Investment outlays of micro and small enterprises in Poland in 2009-2015}

In 2015, the investment outlays of micro and small enterprises in Poland accounted for PLN $24952.0 \mathrm{mln}$ and PLN $15396.6 \mathrm{mln}$ respectively (Table 1). Compared to the previous year, the value of investment outlays was lower by $3.72 \%$ in the case of micro, and $2.57 \%$ in the case of small entities (constant prices ${ }^{3}$ ). In comparison with 2009, there was an increase of $40.18 \%$ and $20.28 \%$ in the investment outlays of micro and small enterprises, respectively (constant prices) (Figure 1).

\section{Table 1}

Investment outlays of non-financial enterprises in Poland (PLN mln; current prices) and their structure (\%) in 2009-2015 by size class of the enterprise

\begin{tabular}{|c|c|c|c|c|c|c|c|}
\hline & 2009 & 2010 & 2011 & 2012 & 2013 & 2014 & 2015 \\
\hline \multicolumn{8}{|c|}{ Investment outlays (PLN mln; current prices) } \\
\hline Total & 128973.7 & 126163.0 & 144702.4 & 138652.6 & 143568.5 & 165603.7 & 181838.9 \\
\hline Micro & 18081.2 & 20954.8 & 23637.3 & 20026.2 & 20416.0 & 25482.8 & 24952.0 \\
\hline Small & 13003.8 & 13447.4 & 15054.7 & 13611.0 & 14117.5 & 15538.1 & 15396.6 \\
\hline Medium & 26821.3 & 25445.9 & 29238.2 & 29097.9 & 30209.0 & 31700.2 & 35568.2 \\
\hline Large & 71067.4 & 66314.9 & 76772.3 & 75917.5 & 78826.0 & 92882.7 & 105922.0 \\
\hline \multicolumn{8}{|c|}{ Structure of investment outlays (\%) } \\
\hline Total & 100.00 & 100.00 & 100.00 & 100.00 & 100.00 & 100.00 & 100.00 \\
\hline Micro & 14.02 & 16.61 & 16.34 & 14.44 & 14.22 & 15.39 & 13.72 \\
\hline Small & 10.08 & 10.66 & 10.40 & 9.82 & 9.83 & 9.38 & 8.47 \\
\hline Medium & 20.80 & 20.17 & 20.21 & 20.99 & 21.04 & 19.14 & 19.56 \\
\hline Large & 55.10 & 52.56 & 53.06 & 54.75 & 54.90 & 56.09 & 58.25 \\
\hline
\end{tabular}

Source: own elaboration based on CSO data (Central Statistical Office, 2011a, 2011b, 2013, 2014a, 2014b, 2015, 2016a).

In the period under review, the decline in investment outlays in 2012 compared to 2011 is particularly noticeable. While in 2012 the reduction in investment outlays affected all size-classes of enterprises, it was most acute for micro and small entities. In their case,

\footnotetext{
${ }^{3}$ With the aim to assess the real dynamics of investment outlays, the price index of investment outlays (in four quarters) was used. It should be noted, however, that the data cover economic entities employing more than 49 persons (with the exception of entities which according to the NACE Rev.2 are classified to sections 'Agriculture, forestry and fisheries' and 'Financial and insurance activities') (Central Statistical Office, 2016b).
} 
investment outlays fell by $16.28 \%$ in micro and $10.66 \%$ in small entities, while in medium and large enterprises this decline was much smaller: $1.66 \%$ and $2.29 \%$ respectively (Figure 1).
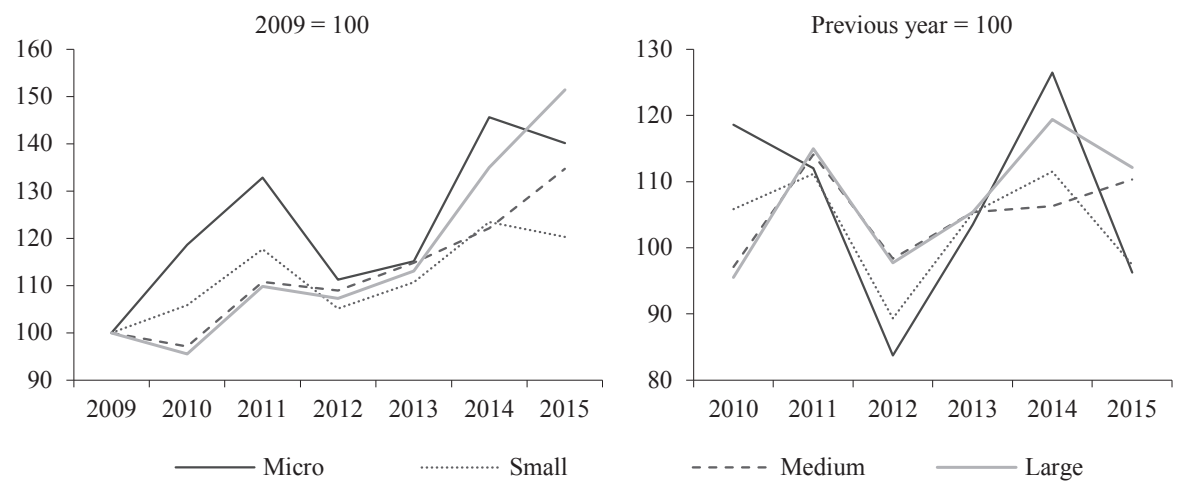

Figure 1. Dynamics of investment outlays by size class of the enterprise $(2009=100$; previous year $=100$; constant prices)

Source: own elaboration based on CSO data (Central Statistical Office, 2011a, 2011b, 2013, 2014a, 2014b, 2015, 2016a).

An analysis of the structure of investment outlays by the size of the enterprise indicates that in 2015 the share of micro-enterprises in the total value of investment outlays amounted to $13.72 \%$, while of small entities to $8.47 \%$ (Table 1). For comparison, at the same time, medium-sized entities generated $19.56 \%$ of the total value of investments, while large entities (representing only $0.2 \%$ of all non-financial enterprises) $58.25 \%$. Over the period under examination, some fluctuations in the shares of particular classes of enterprises in the total value of investment outlays were observed. In the case of micro-enterprises, the share of investment outlays decreased from $14.02 \%$ in 2009 to the above-mentioned $13.72 \%$ in 2015 , reaching the highest in 2010 (16.61\%). Instead, the share of small entities fell from $10.08 \%$ in 2009 to the above-mentioned $8.47 \%$ in 2015 , reaching the highest - as in the case of microenterprises - in 2010 (10.66\%). Despite these changes, the structure of investment outlays by enterprise size remained relatively stable over the period under analysis. The mean share of microenterprises' investment outlays in their total value in 2009-2015 was $14.96 \%$, while that of small entities was $9.81 \%$.

Due to the fact that the value of investment outlays may result from changes in the number of active entities, the analysis of investment activity should also take into account such indicators as the value of investment outlays per enterprise and per person employed.

In 2015 the value of investment outlays per micro-enterprise amounted to PLN 13.57 thousand and per small enterprise to PLN 271.48 thousand (Figure 2). These values evidently indicate the greater investment capacity of small businesses compared to 
micro ones. In 2009-2015, the value of investment outlays per small enterprise was from 18.19 times (in 2014) to 22.99 times (in 2009) higher than the value of investments recorded per micro-enterprise. Over the period under examination, investment outlays per microenterprise increased by $22.34 \%$ and per small enterprise by $6.44 \%$ (constant prices). As in the case of the value of investments, the decrease in investment outlays per entity in 2012 compared to 2011 is observed - by $16.70 \%$ in micro and $13.91 \%$ in small entities (constant prices).
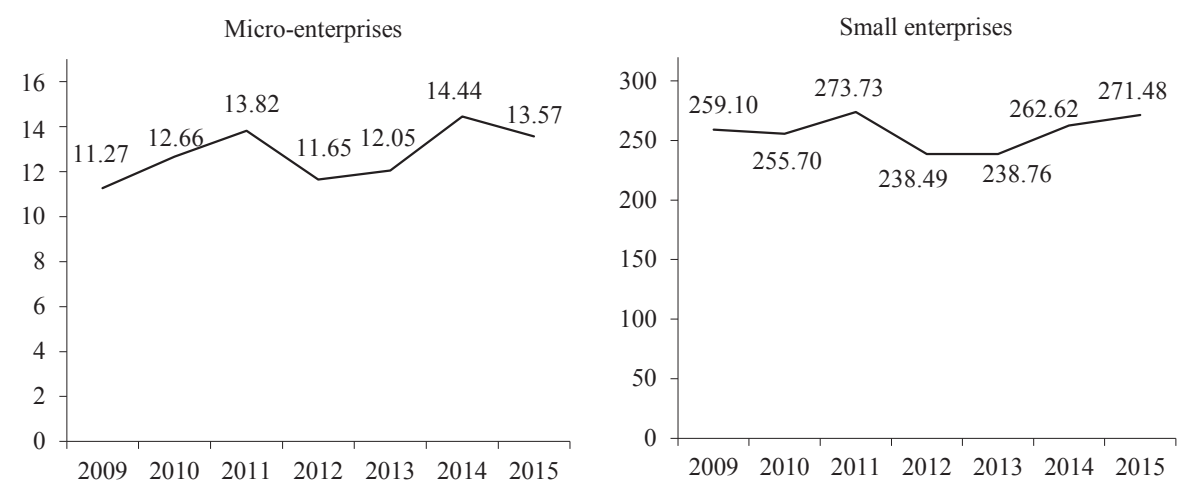

Figure 2. Investment outlays per micro-enterprise and per small enterprise in 2009-2015 (thousands PLN; current prices)

Source: own elaboration based on CSO data (Central Statistical Office, 2011a, 2011b, 2013, 2014a, 2014b, 2015, 2016a).

In 2015, the value of investment outlays per person employed in micro-enterprises amounted to PLN 6.80 thousand, 32.41\% higher than in 2009 (constant prices) (Figure 3). Instead, in small entities the value of investments per person employed was equal to PLN 12.89 thousand, exceeding the value recorded in 2009 by 13.14\% (constant prices). As in the case of investment outlays per entity, these results also confirm the greater investment capacity of small entities compared to micro ones - at the end of the analysed period investment outlays per person employed in small enterprises were 1.90 times higher than recorded for micro entities. This relation, however, was slightly lower than in 2009 (2.22).

The investment activity of enterprises can be also examined with the ratio of investment outlays to enterprises' revenues. In 2015, this ratio for micro and small entities accounted for 2.79 and 2.66\%, respectively (Figure 4). This relation remained rather stable over the period under analysis (coefficients of variation below 10\%). On average, micro and small enterprises spent 2.83 and $2.76 \%$ of their revenues on investments. Comparing to the ratio in question by the size class of the enterprise, it is noted that medium-sized and large enterprises presented slightly higher ratios of investment expenditures to their revenues (on 
average $3.98 \%$ in medium and 5.03\% in large enterprises over 2009-2015) than micro and small ones.

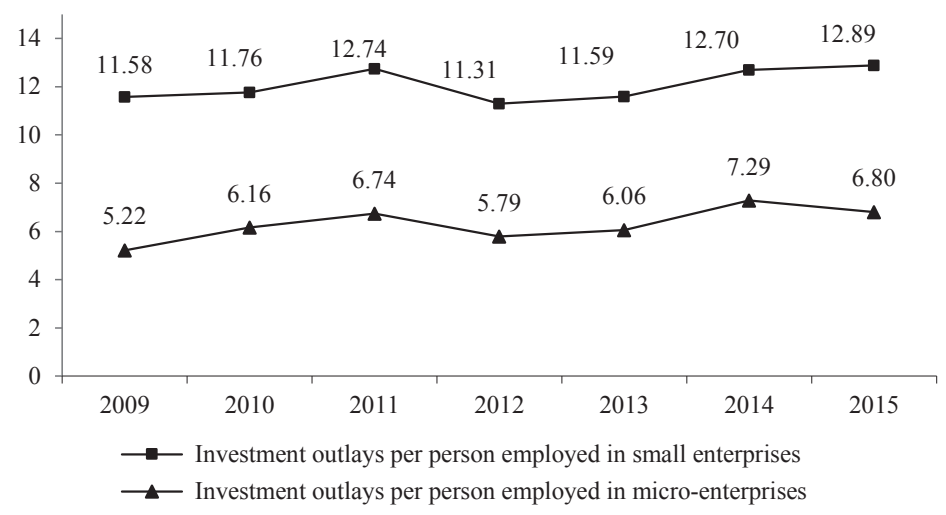

Figure 3. Investment outlays per person employed in micro-enterprises and in small enterprises in 2009-2015 (thousands PLN; current prices)

Source: own elaboration based on CSO data (Central Statistical Office, 2011a, 2011b, 2013, 2014a, 2014b, 2015, 2016a).

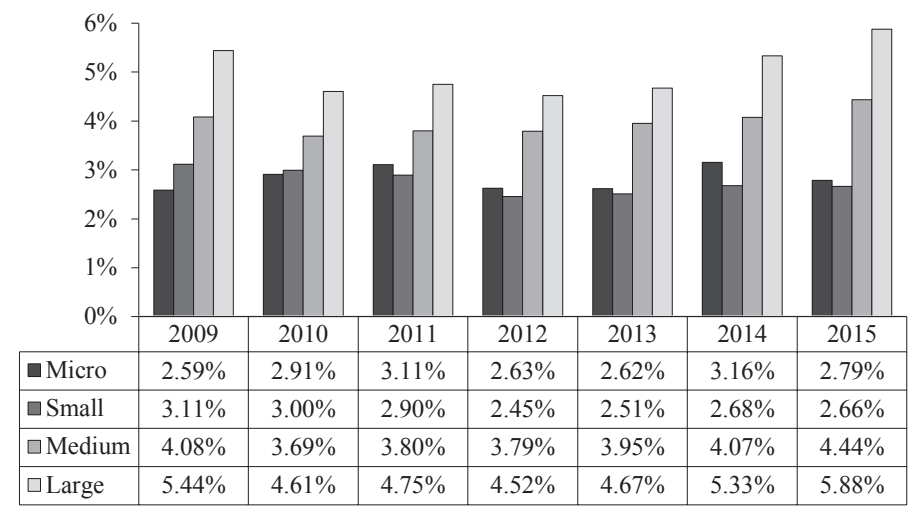

Figure 4. The ratio of investment outlays to revenues in 2009--2015 by size class of the enterprise

Source: own elaboration based on CSO data (Central Statistical Office, 2011a, 2011b, 2013, 2014a, 2014b, 2015, 2016a). 


\section{Spatial differences in the investment outlays of micro and small enterprises in Poland in 2009-2015}

In 2015, the highest values of investment outlays of micro as well as of small enterprises were recorded in the Mazowieckie, Śląskie, and Wielkopolskie voivodeships. These three voivodeships together accounted for $50.81 \%$ of investments by micro entities and $42.72 \%$ of small ones (Table 2). In contrast, the lowest values of investment outlays were recorded by micro entities that had headquarters in the Świętokrzyskie, Lubuskie, and WarmińskoMazurskie voivodeships (in total 5.25\%), and by small entities that had headquarters in the Lubuskie, Opolskie, and Świętokrzyskie voivodeships (in total 7.05\%).

Table 2

Structure of investment outlays of micro and small enterprises in Poland in 2009-2015 by voivodeship

\begin{tabular}{|c|c|c|c|c|c|c|}
\hline \multirow[t]{2}{*}{ Voivodeship } & \multicolumn{2}{|c|}{$\begin{array}{l}\text { Share in 'Total' } \\
2015 \\
(\%)\end{array}$} & \multicolumn{2}{|c|}{$\begin{array}{l}\text { Mean share } \\
2009-2015 \\
(\%)\end{array}$} & \multicolumn{2}{|c|}{$\begin{array}{l}\text { Rank for 'Mean share } \\
\text { 2009-2015' }\end{array}$} \\
\hline & micro & small & micro & small & micro & small \\
\hline Dolnośląskie & 4.52 & 7.14 & 6.55 & 8.29 & 5 & 6 \\
\hline Kujawsko-Pomorskie & 4.12 & 5.34 & 3.69 & 4.62 & 10 & 9 \\
\hline Lubelskie & 3.53 & 3.83 & 3.92 & 3.55 & 9 & 11 \\
\hline Lubuskie & 1.91 & 2.13 & 2.06 & 1.83 & 15 & 16 \\
\hline Łódzkie & 4.92 & 5.23 & 5.22 & 5.15 & 7 & 7 \\
\hline Małopolskie & 7.40 & 9.06 & 7.77 & 8.37 & 4 & 5 \\
\hline Mazowieckie & 30.47 & 20.29 & 25.26 & 18.60 & 1 & 1 \\
\hline Opolskie & 2.06 & 2.35 & 1.86 & 1.87 & 16 & 15 \\
\hline Podkarpackie & 3.55 & 3.60 & 3.56 & 4.67 & 11 & 8 \\
\hline Podlaskie & 2.12 & 2.66 & 2.30 & 2.77 & 14 & 12 \\
\hline Pomorskie & 5.78 & 7.09 & 6.09 & 10.84 & 6 & 3 \\
\hline Śląskie & 8.20 & 12.32 & 8.67 & 11.50 & 3 & 2 \\
\hline Świętokrzyskie & 1.38 & 2.57 & 3.01 & 2.24 & 12 & 14 \\
\hline Warmińsko-Mazurskie & 1.96 & 2.64 & 2.45 & 2.68 & 13 & 13 \\
\hline Wielkopolskie & 12.14 & 10.11 & 12.94 & 9.18 & 2 & 4 \\
\hline Zachodniopomorskie & 5.93 & 3.66 & 4.64 & 3.85 & 8 & 10 \\
\hline
\end{tabular}

Source: own elaboration based on CSO data (Central Statistical Office, 2011a, 2011b, 2013, 2014a, 2014b, 2015, 2016a).

The analysis of the structure of investment outlays by voivodeship indicates that for the period 2009-2015, the highest mean shares in total investments of microenterprises were recorded for the Mazowieckie, Wielkopolskie, and Śląskie voivodeships (Table 2). In the case of small entities, the highest mean shares were observed for the Mazowieckie, Śląskie, and Pomorskie voivodeships. In contrast, at the end of the above ranking are the Podlaskie, Lubuskie, and Opolskie voivodeships when it comes to micro-enterprises, and the Świętokrzyskie, Opolskie, and Lubuskie voivodeships for small entities. Comparing 
with the rankings of voivodeships by the mean share in total investment outlays incurred by micro and small enterprises, a very high compliance of orders is noticed (Spearman's rank correlation $=0.935$ ).

Since a percentage share of each voivodeship in investment outlays might be related to the number of enterprises with headquarters in them, the analysis of spatial differences in investment activity should also include such indicators as the value of investment outlays per entity and per person employed.

In 2015, the highest investment outlays per micro-enterprise were observed in the Mazowieckie, Wielkopolskie, and Zachodniopomorskie voivodeships, while per small enterprise in the Mazowieckie, Pomorskie, and Podlaskie voivodeships (Figure 5). In contrast, the lowest values of investment outlays per micro-enterprise in 2015 were recorded by the Warmińsko-Mazurskie, Dolnoślaskie, and Świętokrzyskie voivodeships, while per small entity by the Lubuskie, Łódzkie, and Podkarpackie voivodeships.
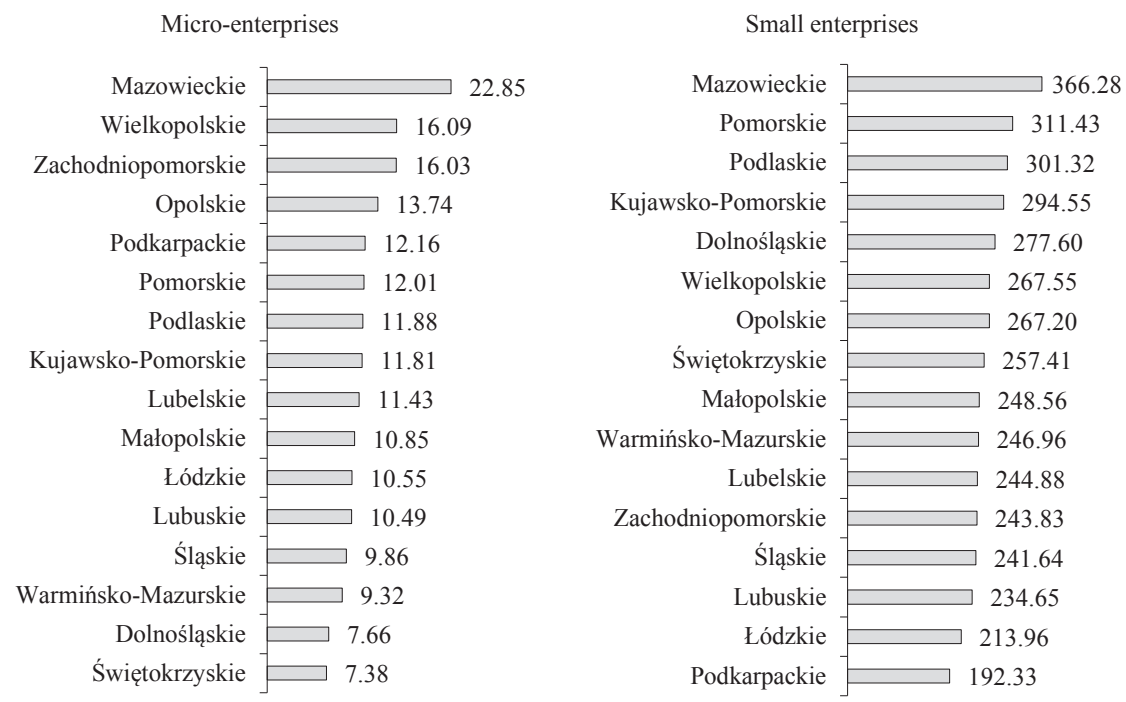

Figure 5. Investment outlays per micro-enterprise and per small enterprise in 2015 by voivodeship (thousands PLN)

Source: own elaboration based on CSO data (Central Statistical Office, 2016a).

With regard to the investment outlays per person employed, in 2015 the top of the ranking was formed by the same voivodeships as in the case of investment outlays per entity (Figure 6). The lowest values of investment outlays per person employed, instead, were recorded for the Śląskie, Dolnoślaskie, and Świętokrzyskie voivodeships in the case of microenterprises, and for the Lubuskie, Łódzkie, and Podkarpackie voivodeships in the case of small entities. 

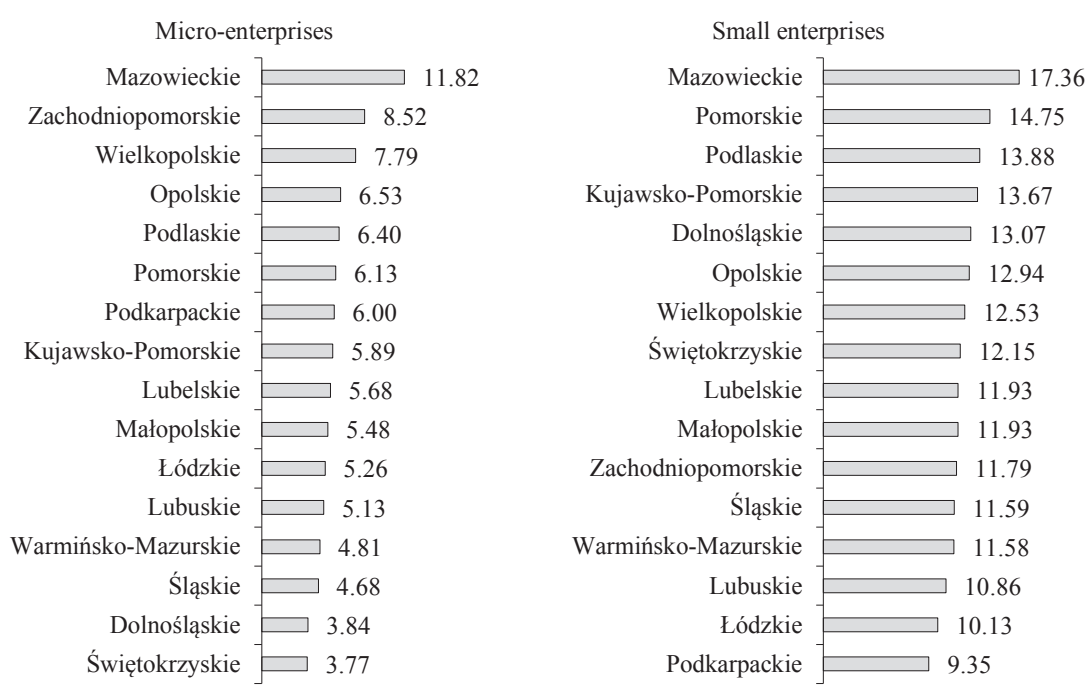

Figure 6. Investment outlays per person employed in micro-enterprises and in small enterprises in 2015 by voivodeship (thousands PLN)

Source: own elaboration based on CSO data (Central Statistical Office, 2016a).

Based on the data on investment outlays per entity in 2009-2015, each voivodeship was assigned to one of the quartile groups, assuming that the first quartile group includes voivodeships with the lowest investment outlays per entity, and the fourth one those with their highest values. The same was done for investment outlays per person employed (Table 3).

As regards small enterprises, the Mazowieckie Voivodeship belonged to the fourth quartile group in all years of the period considered, due to the investment outlays per entity, as well as the investment outlays per person employed. In addition, the most frequent members of this quartile group were the Dolnośląskie (five times/five times ${ }^{4}$ ), Pomorskie (five times/ five times), and Podlaskie (five times/four times) voivodeships, while the first quartile group included most often the Lubuskie (six times/five times), Łódzkie (five times/five times), and Opolskie (four times/five times) voivodeships.

For micro-enterprises, taking into account the frequency of belonging to the fourth quartile group, the leader of the ranking is - as in the case of small entities - the Mazowieckie Voivodeship, due to the investment outlays per entity (seven times), as well as the investment outlays per person employed (six times). The analysis of lower quartile groups, however, indicates that the selection of voivodeships closing the ranking is not as clear as in the case of small entities. In particular, the Śląskie Voivodeship belonged three times/four times

\footnotetext{
${ }^{4}$ The first number refers to the investment outlays per entity, and the second one to the investment outlays per person employed.
} 
Table 3

Quartile groups of voivodeships by investment outlays per entity/per person employed" in micro and small enterprises in 2009-2015

\begin{tabular}{|c|c|c|c|c|c|c|c|c|c|c|c|c|c|c|}
\hline \multirow[b]{2}{*}{ Voivodeship } & \multicolumn{7}{|c|}{ Micro } & \multicolumn{7}{|c|}{ Small } \\
\hline & 용 & $\stackrel{\circ}{\stackrel{0}{0}}$ & $\bar{\Xi}$ & $\stackrel{\sim}{\stackrel{N}{0}}$ & $\frac{m}{2}$ & $\underset{\circlearrowright}{\stackrel{Ð}{\delta}}$ & $\frac{n}{\circ}$ & ஓి & $\stackrel{0}{\frac{0}{0}}$ & $\bar{\Xi}$ & $\frac{\sim}{\stackrel{N}{c}}$ & $\frac{m}{\stackrel{n}{\sigma}}$ & $\underset{\mathrm{D}}{\stackrel{\Delta}{\circ}}$ & $\frac{n}{\circ}$ \\
\hline Dolnośląskie & $2 / 1$ & $3 / 3$ & $1 / 1$ & $3 / 3$ & $4 / 4$ & $2 / 2$ & $1 / 1$ & $4 / 4$ & $4 / 4$ & $4 / 4$ & $4 / 4$ & $3 / 3$ & $4 / 4$ & $3 / 3$ \\
\hline Kujawsko-Pomorskie & $1 / 1$ & $1 / 1$ & $1 / 1$ & $2 / 2$ & $2 / 2$ & $2 / 3$ & $3 / 3$ & $2 / 1$ & $3 / 3$ & $3 / 3$ & $3 / 3$ & $3 / 2$ & $2 / 2$ & $4 / 4$ \\
\hline Lubelskie & $3 / 3$ & $2 / 2$ & $4 / 4$ & $2 / 2$ & $3 / 3$ & $4 / 3$ & $2 / 2$ & $2 / 2$ & $2 / 2$ & $3 / 3$ & $1 / 2$ & $1 / 1$ & $2 / 2$ & $2 / 2$ \\
\hline Lubuskie & $1 / 1$ & $3 / 3$ & $2 / 2$ & $4 / 4$ & $1 / 2$ & $1 / 1$ & $2 / 2$ & $1 / 2$ & $1 / 1$ & $1 / 1$ & $1 / 1$ & $2 / 2$ & $1 / 1$ & $1 / 1$ \\
\hline Łódzkie & $1 / 1$ & $1 / 1$ & $3 / 3$ & $3 / 3$ & $1 / 1$ & $2 / 2$ & $2 / 2$ & $1 / 1$ & $1 / 1$ & $1 / 1$ & $2 / 2$ & $2 / 2$ & $1 / 1$ & $1 / 1$ \\
\hline Małopolskie & $2 / 2$ & $4 / 4$ & $3 / 3$ & $3 / 3$ & $3 / 3$ & $1 / 1$ & $2 / 2$ & $3 / 3$ & $1 / 1$ & $2 / 2$ & $2 / 2$ & $3 / 3$ & $2 / 3$ & $2 / 2$ \\
\hline Mazowieckie & $4 / 4$ & $4 / 4$ & $4 / 3$ & $4 / 4$ & $4 / 4$ & $4 / 4$ & $4 / 4$ & $4 / 4$ & $4 / 4$ & $4 / 4$ & $4 / 4$ & $4 / 4$ & $4 / 4$ & $4 / 4$ \\
\hline Opolskie & $3 / 3$ & $3 / 3$ & $2 / 2$ & $1 / 1$ & $3 / 3$ & $3 / 3$ & $4 / 4$ & $1 / 1$ & $1 / 1$ & $1 / 1$ & $2 / 1$ & $2 / 2$ & $1 / 1$ & $3 / 3$ \\
\hline Podkarpackie & $4 / 3$ & $3 / 3$ & $2 / 2$ & $1 / 1$ & $4 / 4$ & $3 / 3$ & $3 / 3$ & $2 / 2$ & $2 / 2$ & $3 / 3$ & $3 / 3$ & $4 / 4$ & $4 / 4$ & $1 / 1$ \\
\hline Podlaskie & $3 / 4$ & $2 / 2$ & $3 / 4$ & $2 / 2$ & $3 / 3$ & $4 / 4$ & $3 / 3$ & $3 / 3$ & $4 / 3$ & $4 / 4$ & $4 / 4$ & $4 / 4$ & $3 / 3$ & $4 / 4$ \\
\hline Pomorskie & $4 / 4$ & $1 / 1$ & $1 / 1$ & $4 / 4$ & $2 / 2$ & $4 / 4$ & $3 / 3$ & $4 / 4$ & $4 / 4$ & $4 / 4$ & $4 / 4$ & $3 / 3$ & $3 / 3$ & $4 / 4$ \\
\hline Śląskie & $2 / 2$ & $2 / 1$ & $2 / 2$ & $2 / 2$ & $1 / 1$ & $1 / 1$ & $1 / 1$ & $2 / 2$ & $2 / 2$ & $2 / 2$ & $2 / 2$ & $2 / 3$ & $3 / 3$ & $1 / 2$ \\
\hline Świętokrzyskie & $3 / 3$ & $4 / 4$ & $4 / 4$ & $4 / 4$ & $1 / 1$ & $1 / 1$ & $1 / 1$ & $1 / 1$ & $2 / 2$ & $1 / 1$ & $1 / 1$ & $1 / 1$ & $4 / 4$ & $3 / 3$ \\
\hline Warmińsko-Mazurskie & $2 / 2$ & $2 / 2$ & $3 / 3$ & $1 / 1$ & $2 / 2$ & $2 / 2$ & $1 / 1$ & $3 / 3$ & $3 / 4$ & $3 / 3$ & $1 / 1$ & $1 / 1$ & $3 / 2$ & $2 / 1$ \\
\hline Wielkopolskie & $4 / 4$ & $4 / 4$ & $4 / 4$ & $3 / 3$ & $2 / 1$ & $3 / 2$ & $4 / 4$ & $4 / 4$ & $3 / 3$ & $2 / 2$ & $3 / 3$ & $1 / 1$ & $2 / 2$ & $3 / 3$ \\
\hline Zachodniopomorskie & $1 / 1$ & $1 / 2$ & $1 / 1$ & $1 / 1$ & $4 / 4$ & $3 / 4$ & $4 / 4$ & $3 / 3$ & $3 / 3$ & $2 / 2$ & $3 / 3$ & $4 / 4$ & $1 / 1$ & $2 / 2$ \\
\hline
\end{tabular}

"The first number indicates the number of the quartile group due to the investment outlays per entity; the second one refers to the number of the quartile group due to the investment outlays per person employed.

Source: own elaboration based on CSO data (Central Statistical Office, 2011a, 2011b, 2013, 2014a, 2014b, 2015, 2016a).

\section{Table 4}

The ratio of investment outlays to revenues for micro and small enterprises in 2009-2015

- the minimum and maximum value, maximum/minimum ratio, and the range due to voivodeship

\begin{tabular}{lllllllll}
\hline & & 2009 & 2010 & 2011 & 2012 & 2013 & 2014 & 2015 \\
\hline \multirow{5}{*}{ Micro } & $\max (\%)$ & 3.80 & 5.96 & 5.94 & 5.09 & 5.66 & 5.20 & 3.84 \\
& $\min (\%)$ & 1.53 & 1.73 & 2.16 & 1.85 & 1.45 & 1.79 & 1.70 \\
& $\max / \min$ & 2.48 & 3.44 & 2.76 & 2.75 & 3.92 & 2.91 & 2.26 \\
& $\operatorname{range}(\mathrm{pp})$ & 2.27 & 4.23 & 3.79 & 3.24 & 4.22 & 3.42 & 2.14 \\
\hline \multirow{3}{*}{ Small } & $\max (\%)$ & 8.67 & 7.17 & 7.18 & 3.68 & 4.79 & 4.35 & 3.51 \\
& $\min (\%)$ & 2.00 & 2.24 & 2.10 & 1.76 & 1.72 & 1.91 & 2.13 \\
& $\max / \min$ & 4.34 & 3.20 & 3.43 & 2.09 & 2.78 & 2.28 & 1.65 \\
& $\operatorname{range}(\mathrm{pp})$ & 6.67 & 4.93 & 5.09 & 1.92 & 3.07 & 2.44 & 1.38 \\
\hline
\end{tabular}

Source: own elaboration based on CSO data (Central Statistical Office, 2011a, 2011b, 2013, 2014a, 2014b, 2015, 2016a). 
to the first quartile group and four times/three times to the second quartile group due to the investment outlays per entity/per person employed.

An analysis of the ratio of investment outlays to revenues indicates the differences between voivodeships, both when talking about micro and small enterprises (Table 4). For micro entities, the difference between the highest and lowest value of this ratio was from $2.14 \mathrm{pp}$ (in 2015) to $4.23 \mathrm{pp}$ (in 2010), while for small enterprises from $1.38 \mathrm{pp}$ (in 2015) to $6.67 \mathrm{pp}$ (in 2009). The maximum value of the ratio in question was from 2.26 (in 2015) to 3.92 (in 2013) times higher than its minimum value in the case of micro-enterprises and from 1.65 (in 2015) to 4.34 (in 2009) times higher in the case of small ones.

\section{Concluding remarks}

The results of the empirical research on the investment activity of non-financial micro and small enterprises in Poland in 2009-2015 allow the following conclusions to be drawn: 1) the shares of micro and small enterprises in the total value of investment outlays were rather stable over the period under analysis; 2) from 2009 to 2015 the investment outlays of both micro and small enterprises increased; in relative terms, however, this increase was stronger for micro-entities than for small ones (this applies to the value of investment outlays, as well as to investment outlays per entity and per person employed); 3) the year 2012 was marked by a decrease in investment outlays in all of the size-classes of enterprises, although it was most severe for micro and small entities; 4) micro and small enterprises presented slightly lower ratios of investment expenditures to their revenues than medium and large ones; 5) an analysis of the structure of investment outlays by voivodeship in 2015 indicates their high degree of concentration in the Mazowieckie, Wielkopolskie, and Śląskie voivodeships; however, these voivodeships in total account for nearly $40 \%$ of micro and small enterprises; 6) an analysis of investment outlays per entity and per person employed reveals differences between voivodeships in their values; in addition, an analysis of the above categories in 2009-2015 shows changes in their level for individual voivodeships over time resulting in variation in the composition of quartile groups constituted for investment outlays per entity and per person employed; 7) an analysis of the ratio of investment outlays to revenues in 2009-2015 indicates differences in its value between voivodeships.

\section{References}

Central Statistical Office. (2011a). Activity of non-financial enterprises in 2009. Warsaw: CSO. Retrieved from: http://stat.gov.pl.

Central Statistical Office. (2011b). Activity of non-financial enterprises in 2010. Warsaw: CSO. Retrieved from: http://stat.gov.pl.

Central Statistical Office. (2013). Activity of non-financial enterprises in 2011. Warsaw: CSO. Retrieved from: http://stat.gov.pl.

Central Statistical Office. (2014a). Activity of non-financial enterprises in 2012. Warsaw: CSO. Retrieved from: http://stat.gov.pl. 
Central Statistical Office. (2014b). Activity of non-financial enterprises in 2013. Warsaw: CSO. Retrieved from: https://stat.gov.pl.

Central Statistical Office. (2015). Activity of non-financial enterprises in 2014. Warsaw: CSO. Retrieved from: http://stat.gov.pl.

Central Statistical Office. (2016a). Activity of non-financial enterprises in 2015. Warsaw: CSO. Retrieved from: https://stat.gov.pl.

Central Statistical Office. (2016b). Price indices - quarterly indicators. Data file. Retrieved from: http://bdm.stat. gov.pl.

Czerwonka, L., Jaworski, J. (2014a). Inwestycje polskich podmiotów gospodarczych w środki trwałe i źródła ich finansowania w latach 2001-2010. Zeszyty Naukowe Uniwersytetu Szczecińskiego, 804. Finanse, Rynki Finansowe, Ubezpieczenia, 67, 279-293.

Czerwonka, L., Jaworski, J. (2014b). Źródła finansowania inwestycji w wartości niematerialne i prawne podmiotów gospodarczych w Polsce w latach 2001-2010. Zeszyty Naukowe Wyższej Szkoły Bankowej we Wrocławiu, 5 (43), 65-75.

Jaworek, M., Kuzel, M. (2013). Aktywność inwestycyjna największych przedsiębiorstw w Polsce. Studia Ekonomiczne. Zeszyty Naukowe Uniwersytetu Ekonomicznego w Katowicach, 155, 314-322.

Jędrzejczak-Gas, J. (2014). Aktywność inwestycyjna małych i średnich przedsiębiorstw w województwie lubuskim. Zeszyty Naukowe Polskiego Towarzystwa Ekonomicznego w Zielonej Górze, 1, 102-118.

Jędrzejczak-Gas, J. (2016). Aktywność inwestycyjna małych i średnich przedsiębiorstw w województwie dolnośląskim. Zeszyty Naukowe Dolnośląskiej Wyższej Szkoly Przedsiębiorczości i Techniki w Polkowicach. Studia z Nauk Spolecznych, 9, 271-286.

Piwowarski, P. (2014). Inwestycje a wielkość przychodów sektora MSP w Polsce. Annales Universitatis Mariae Curie-Skłodowska. Sectio H, Oeconomia, 2 (48), 91-100.

Skowronek-Mielczarek, A. (2013). Uwarunkowania rozwoju matych i średnich przedsiębiorstw w Polsce. Warszawa: Oficyna Wydawnicza SGH.

Starzyńska, D. (2016). Aktywność inwestycyjna przedsiębiorstw sektora MSP w Polsce w latach 2009-2013. Przedsiębiorczość i Zarządzanie, 10 (17), 117-132.

Szafraniec-Siluta, E., Zawadzka, D., Strzelecka, A. (2012). Aktywność inwestycyjna przedsiębiorstw rolniczych Pomorza Środkowego. Zeszyty Naukowe Szkoły Głównej Gospodarstwa Wiejskiego w Warszawie. Ekonomika i organizacja gospodarki żywnościowej, 97, 93-110.

\section{PRZESTRZENNE ZRÓŻNICOWANIE NAKŁADÓW INWESTYCYJNYCH MIKRO I MALYCH PRZEDSIĘBIORSTW W POLSCE}

Streszczenie: $\mathrm{Cel}$ - Celem artykułu jest analiza przestrzennego zróżnicowania nakładów inwestycyjnych mikro i małych przedsiębiorstw w Polsce na poziomie województw w latach 2009-2015.

Metodologia badania - Badanie przeprowadzono na podstawie danych GUS za lata 2009-2015. Metody badawcze zastosowane w pracy obejmują analizę struktury i dynamiki nakładów inwestycyjnych niefinansowych mikro i małych przedsiębiorstw w Polsce. W celu oceny aktywności inwestycyjnej mikro i małych przedsiębiorstw wyznaczono takie wielkości jak: nakłady inwestycyjne na podmiot, nakłady inwestycyjne na pracującego, relację nakładów inwestycyjnych do przychodów.

Wynik - Analiza danych GUS wskazuje na różnice między województwami w zakresie aktywności inwestycyjnej mikro i małych przedsiębiorstw w Polsce mierzonej nakładami inwestycyjnymi na podmiot, nakładami inwestycyjnymi na pracującego oraz relacją nakładów inwestycyjnych do przychodów.

Oryginalność/wartość - Ponieważ wiele z prowadzonych badań dotyczy grupy małych i średnich przedsiębiorstw (MŚP) jako całości, niniejszy artykuł, koncentrując się na aktywności inwestycyjnej osobno mikro i małych podmiotów, stanowi wkład do literatury z zakresu funkcjonowania mikro i małych przedsiębiorstw w Polsce.

Słowa kluczowe: nakłady inwestycyjne, aktywność inwestycyjna, mikro i małe przedsiębiorstwa

\section{Citation}

Ziętek-Kwaśniewska, K. (2018). Spatial differences in investment outlays of micro and small enterprises in Poland. Finanse, Rynki Finansowe, Ubezpieczenia, 1 (91), 137-148. DOI: 10.18276/frfu.2018.91-12. 